\title{
STUDY ON THE CAUSES OF FACTORS AND PUBLIC RESPONSE TO PROSTITUTIONAL PRACTICES IN TOURISM OBJECT OF BUKIT LAWANG
}

\author{
By \\ Krista Surbakti \\ Universitas Quality \\ Email: Kristasurbakti84@gmail.com
}

\begin{abstract}
PSK (Penjajah Seks Komersial) or prostitutes are women who sell their bodies to sexually satisfy any man who wants them, where the woman receives a certain amount of money or goods (generally with money from the man who uses it). In today's life, the existence of prostitutes or often called WTS (Tuna Susila) is a familiar phenomenon in the life of Indonesian society, but this existence still causes pros and cons in society. It is possible that until now there has been no answer that is felt to accommodate the concept of commercial sex workers itself. This is largely because they are unable to cover the cost of living. Prostitution here is not merely a symptom of moral violation but is a trading activity. This prostitution activity lasts quite a long time, this may be due to the fact that in practice these activities take place because of the high demand from consumers for sexual activity services, the more the level of supply offered. When viewed from a broad perspective, we will find that what commercial sex workers actually do is a trafficking network that involves many parties. This trade network also stretches over a wider area, sometimes not only within a country but several countries.

It is therefore necessary to acknowledge that sexual exploitation, prostitution and human trafficking are all acts of violence against women and therefore constitute a violation of the dignity of women and also a serious violation of human rights. The number of female sex workers has increased dramatically around the world for a number of economic, social and cultural reasons. In certain cases the women involved have experienced pathological violence or sexual crimes since childhood, others fall into the trap of making ends meet for themselves or their families, some seek a father figure or a love relationship with a man, others because it is to pay off a debt. . Many of them enter the world of prostitution because of the assumption that the jobs they offer will change their lives.
\end{abstract}

\section{INTRODUCTION}

Prostitution is a social problem because it deviates from the norms and values of society. Many terms are used to refer to perpetrators of prostitution such as WTS, prostitutes, prostitutes, balloons, sundel and night butterflies. Prostitution has existed since ancient times until now, but no one knows for sure when the emergence of prostitution. It is said that the problem of prostitution was born along with the birth of marriage norms. The prostitution activity is to have sexual relations with men outside of marriage and changing partners, and to do so accept money or other forms of material. The understanding of WTS according to Soedjono D. (1977) is as follows: "Susila Tuna 
women or prostitutes are women who sell their bodies to sexually satisfy any man who wants them, wherein the woman receives a sum of money or goods (generally with money from the male user).

In this life, the existence of Susuna Tuna Woman or often called CSW is a familiar phenomenon in the life of Indonesian people, but the existence is apparently still cause pros and cons in society. Question, are sex workers among those who are excluded or those who are insulted? It is possible that until now there has been no answer that is felt to be able to accommodate the concept of commercial sex workers themselves. This is largely because they cannot bear the cost of living. Prostitution here is not merely a symptom of moral violations but is a trading activity. Prostitution activities lasted quite a long time, this might be due to the fact that in practice these activities took place because of the large number of requests from consumers for sexual activity services. Therefore more and more levels of offer are offered.

When viewed from a broad perspective, we will know that what commercial sex workers actually do is a trading network that involves many parties. This trade network also extends in a wider area, sometimes not only within a country but several countries. Therefore it needs to be recognized that sexual exploitation, prostitution and human trafficking are all acts of violence against women and are therefore a violation of the dignity of women and are also gross violations of human rights. The number of women sex workers has increased dramatically throughout the world due to a number of economic, social and cultural reasons.

In certain cases the women involved have experienced pathological violence or sexual crimes since childhood. Others fall into in order to earn a living that is adequate for themselves or their families, some are looking for a father figure or a love relationship with a man, others are due to pay off debts. Some left poverty in their home regions, in the belief that the work offered would change their lives.

\section{METHOD}

In examining this problem, researchers used qualitative methods. The qualitative method as a research procedure that produces descriptive data in the form of written and oral words from the people observed. This method uses a method or research technique that makes the description as clear as possible about the object to be examined and will explain in fact the characteristics of the population in the field. Descriptive research can be interpreted as a problem-solving procedure that will be investigated with describe or describe the state of the subject and object of research at the present time based on facts or as it is, Meleong (2011). Descriptive method is finding facts with the right interpretation. 
INA-Rxiv Journal Print-ISSN: 2059-1209 Online-ISSN: 2059-1217 doi: 10.31227/osf.io/v2ysf

Descriptive research studies the problems in society and the procedures that apply in society and certain situations, including the relationship of activities, attitude, views and processes that take place and the effects of a phenomenon. Research subjects or respondents are the parties used as samples in a study. Research subjects also discussed the characteristics of the subjects used in the study, including an explanation of the population, samples and sampling techniques (random / nonrandom) used. Therefore the respondents / samples in this study are:
A. Prostitutes
B. Pimp / Pimp.

\section{DISCUSSION}

Bukit Lawang village is relatively busy at night, with a terminal a little far from the cafes in the new Bandar Village. The cafe in Bukit Lawang Village is a hangout for commercial sex workers who come from various regions. They sit in groups with celebritystyle makeup while accompanying the guests who stop by or intend to use the sex services available at the cafe. PSK hopes that the guests will join them and drink together and be paid by the guests who come, both soft drinks and hard drinks, while offering themselves to be visited by guests both overnight (check in) or just one hour (short time). For dating, not all prostitutes who are there can be taken out of the cafe. There are also those who are just as enticing guests. Their working hours start from 18.00 until 02.00 WIB. They are not allowed by the cafe owner to get out of the cafe, but must invite their guests to drink at the cafe first. After working hours, they can leave.

The establishment of the cafes, more complete nightlife in the village of Bukit Lawang, on a normal day that is Monday to Saturday, the cafes start crowded after 21:00 WIB and on Saturdays and Sundays, the crowd can already be seen at 19:00 WIB. The cafes are located not far from the edge of the Bukit Lawang river, it further adds to the glamor of the night atmosphere at the location. In front of the cafe looks a car park yard, which has a rhythm and the ritual itself accompanies dangdut music and disco music that is heard through the sidelines of the wall. 
INA-Rxiv Journal Print-ISSN: 2059-1209 Online-ISSN: 2059-1217 doi: 10.31227/osf.io/v2ysf

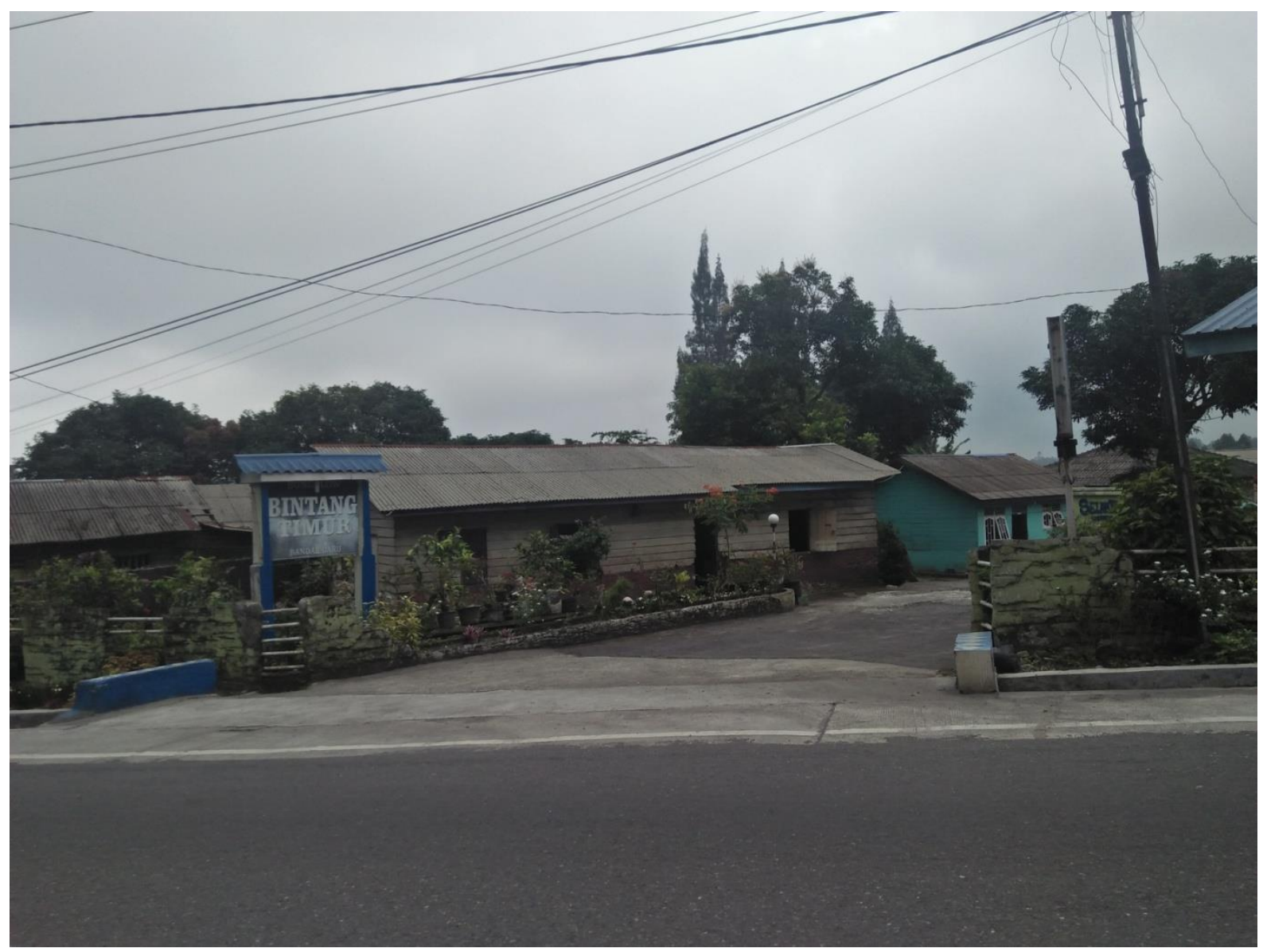

On the page there are cigarette traders who are always loyal to accompany the parking interpreter who oversees various brands of cars and motorcycles. The cafes in Bukit Lawang are a strategic place for fun. Men who come to this place solely for fun. The cafe provides entertainment, drinks and women. If guests who want to enter are already at the door of the cafe, they will immediately be welcomed and served. It will not be difficult to get a drinking buddy as well as a date for cafe guests, the prostitutes are ready to serve them.

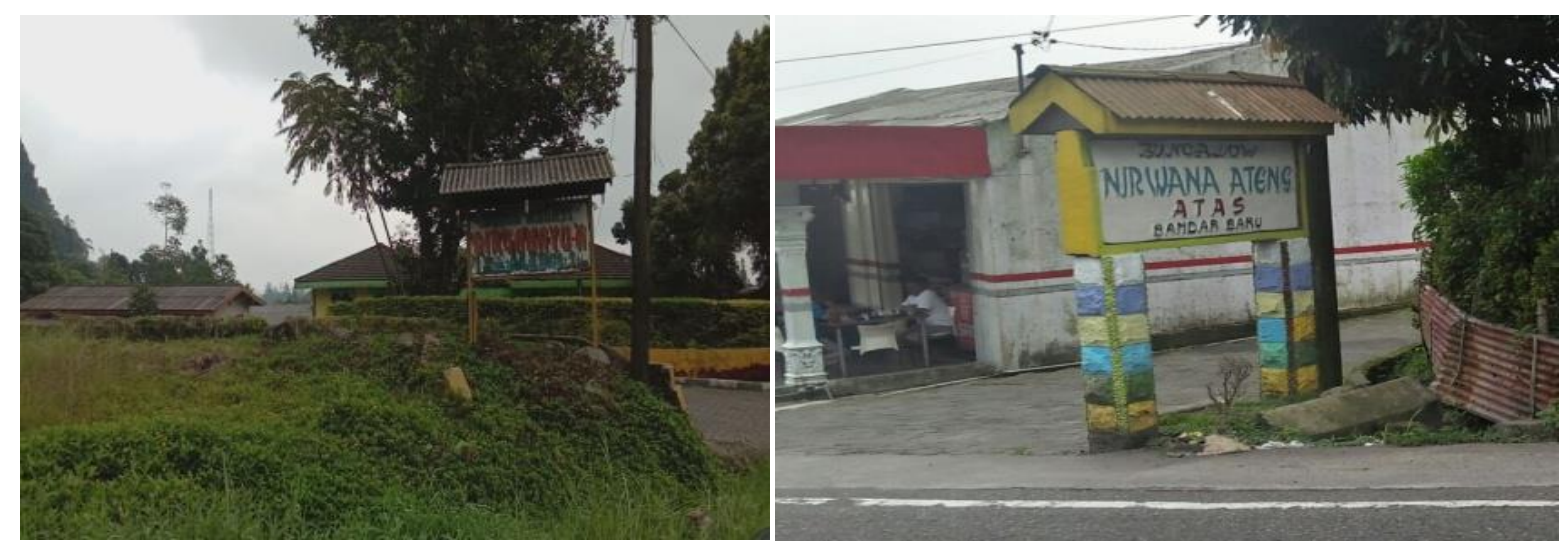

In Bukit Lawang Village there are also many Melati hotels that are relatively affordable for guests, with modest buildings sufficient for a hotel. There are several hotels that also provide a cafe 
to relax. In this cafe also the prostitutes offered him to be taken to the hotel in order to stay overnight, check in.
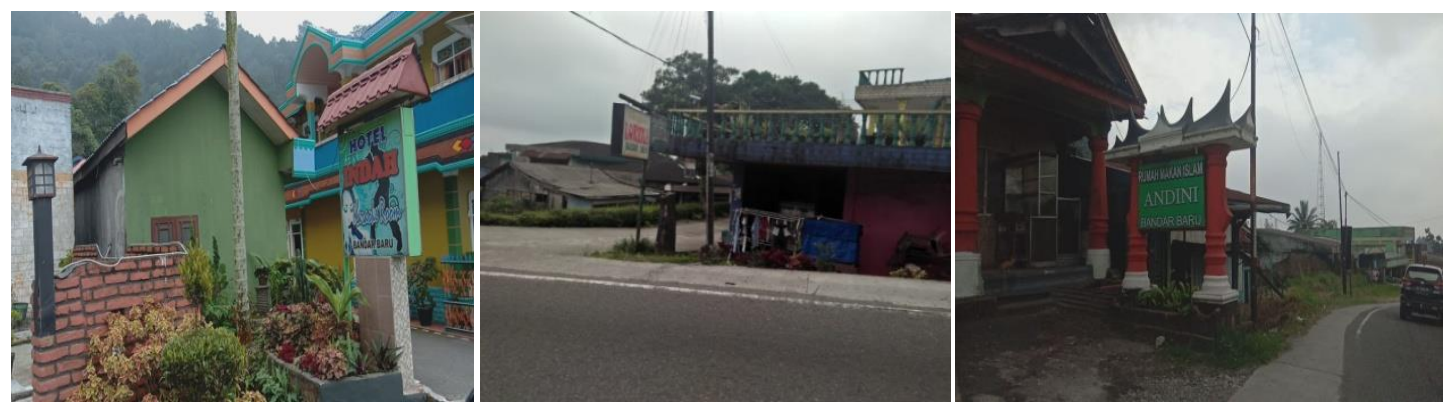

PSK that researchers met, not all of them can sell services from their bodies in one night. Some commercial sex workers only accompany drinking men who come and hope to get tips from customers they have accompanied to drink. Various reasons that were offered by the prostitutes why in one night they could not get even one male customer To add money, PSK must speculate to get it. Merchandise in the cafe is another alternative that can give them the ease to earn extra money. How not, how the transactions carried out by the prostitutes are not in accordance with outside circumstances or the market. If the guests drink in the cafe more expensive than drinking outside. That's natural, because the expensive one is not the drink but the place. According to them, bottled tea for example, prices range up to Rp. 30,000.- If a person drinks beer the price is more expensive than usual and prostitutes sometimes have a cheating habit, that is when guests are drunk then a drink bottle is added on the table so that the count will increase. 


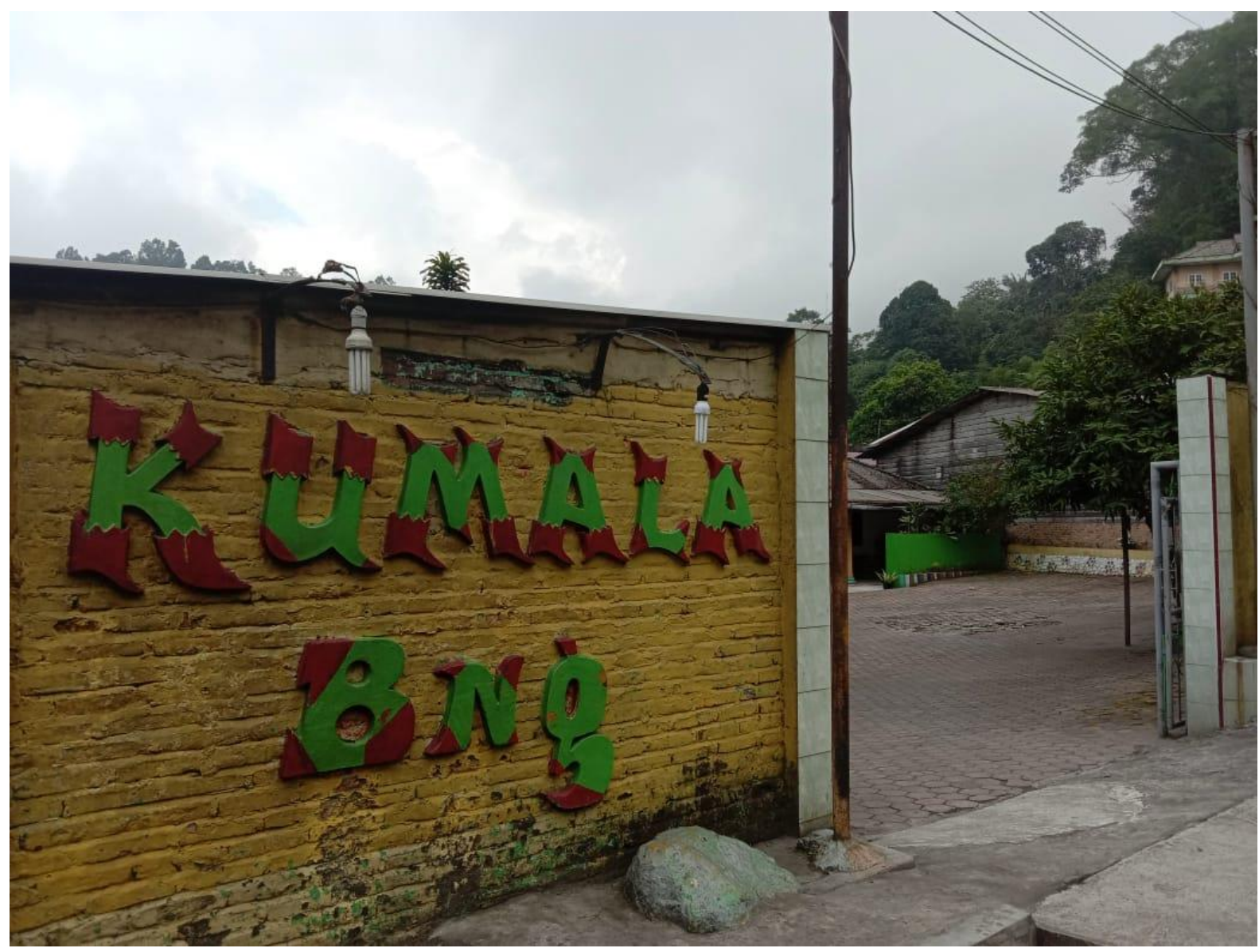

The owners of cafes in Desa Bandar Baru are, on average, local people. But there are also those who come from outside the new Bukit Lawang area. One of the cafes owned by an original man born in Bukit Lawang, where the cafe is located not far from the riverbank employing four prostitutes who come from outside the area. Two of the sex workers came from Besitang, while the other two came from Pandanus Dressing. They all accompanied drinking and at the same time accompanied the dates of the guests who intended to vent their lust.

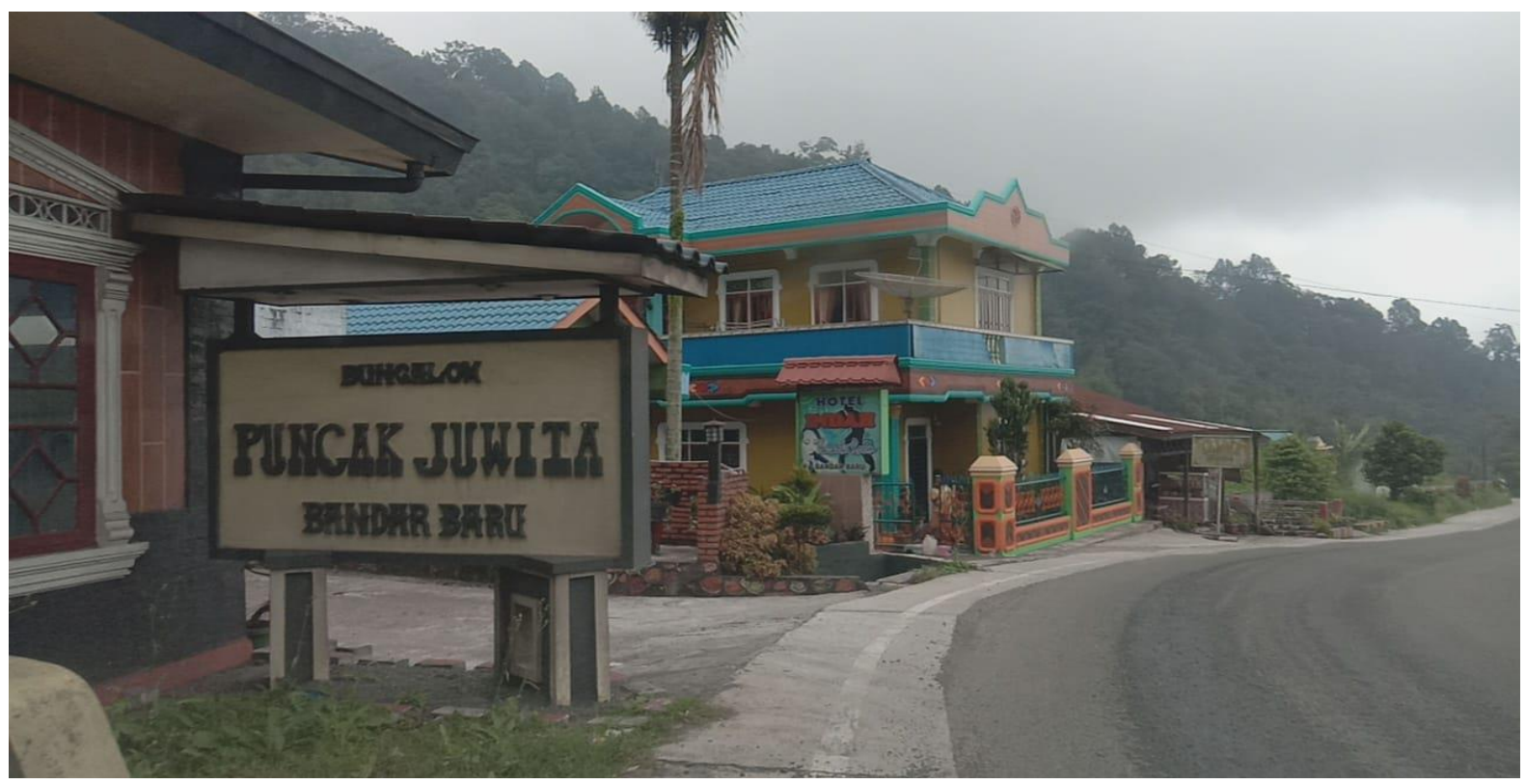


In other places, there is a cafe that sells quite well every night and is located not far from the cafe Wati. The owner is a young boy named Andi who is still 25 years old and assisted by his younger sister. Their presence enlivened the progress of the nightlife in Bukit Lawang. Cafe Andi is open from 20.00 until 03.00 WIB. Andi along with his younger sister jointly manage the cafe, and took turns guarding the cafe in order to get a living. Andi is very disciplined with his younger siblings. In the morning, Andi's younger sister attends school and after school, immediately does her homework and homework. At night he also helps Andi keep the cafe. Andi employs four prostitutes in his café. On Saturdays and Sundays is the most crowded day of visitors, because guests are so crowded the two brothers are often assisted and accompanied by their parents.

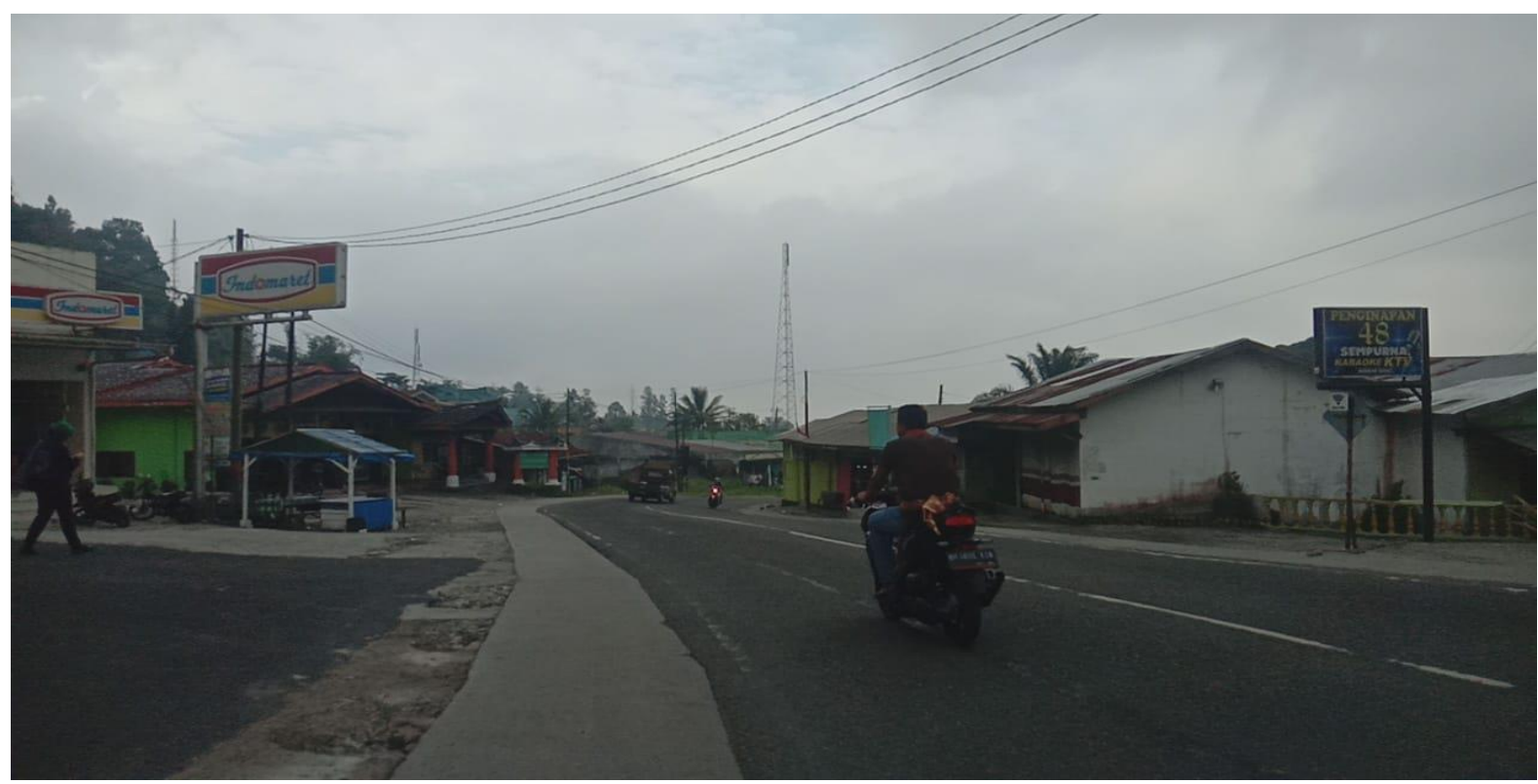

Cafes usually operate at night but there are also cafes that operate during the day. The cafe which has rooms but the cafe does not operate, still receives guests who want to stay. The hotel operates daily both day and night. Prostitution activities sometimes occur during the day at hotels and cafes in Bukit Lawang.

\section{REFERENCES}

Azwar, S., 2012, Metode Penelitian, Yogyakarta: Pustaka Pelajar

Hakim,Vita Amaliah, 2014. Analisis Efektivitas Pajak Daerah dan Retribusi Daerah Terhadap Pendapatan Asli Daerah (PAD) Kota Tasikmalaya (Studi Kasus Pada Dinas Pendapatan Kota Tasikmalaya). Tasikmalaya.

Kartono, K., 2011, Patologi Sosial, Jakarta: Raja Grafindo Persada.

Meleong, Lexy.J .2009, Metode Penelitian Kualitatif. Bandung : PT. Remaja Rosdakarya.

Pulungan, anwar. 2014, Analisis Faktor-Faktor Yang Mempengaruhi Pajak Daerah. Skripsi Fakultas Ekonomi, Universitas Sumatera Utara.

Prastya RK., C., dan Darma, A., 2011, Dolly: Kisah Pilu yang Terlewatkan, Yogyakarta: Pustaka Pena. 
INA-Rxiv Journal Print-ISSN: 2059-1209 Online-ISSN: 2059-1217 doi: 10.31227/osf.io/v2ysf

Satyawan, H., 2009, Persepsi Stakeholder Terhadap Lokalisasi Villa Garden di Kabupaten Karimun, Tesis: Universitas Gadjah Mada.

Silalahi, U., 2010, Metode Penelitian Sosial, Bandung: Refika Aditama.

Sugiyono, 2012, Metode Penelitian Kuantitatif Kualitatif dan R\&D, Bandung: Alfabeta

Suhadak \& Trilaksono, 2012, Pendapatan Asli daerah, Gramedia.

Surbakti, K. (2018). FOSTERING OF FEMALE PRISONERS IN TANJUNG GUSTA PENITENTIARY OF MEDAN. PROCEEDING: THE DREAM OF MILLENIAL GENERATION TO GROW, 216-225.

Suyanto, B., 2012, Anak Perempuan Yang Dilacurkan: Korban Eksploitasi di Industri Seksual Komersial, Yogyakarta: Graha IImu.

Syam, N., 2011, Agama Pelacur: Dramaturgi Transendental, Yogyakarta: LKiS.

UU No. 12 Tahun 2007 tentang Otonomi Daerah.

UU No. 28 Tahun 2009 tentang Pajak Daerah dan Retribusi Daerah.

UU No. 33 Tahun 2004 tentang Perimbangan Keuangan Antara Pemerintah Pusat dan Pemerintah Daerah 